\title{
The International and
}

\section{Comparative Law Quarterly}

VOLUME 14

1965

William S. Hein \& Co., Inc.

Buffalo, New York

2003 
- British Institute of International and Comparative Law 1965.

Published by Oxford University Press.

All rights reserved

This book has been digitally archived, to maintain the quality of the original work for future generations of legal researchers, by William S. Hein \& Co., Inc.

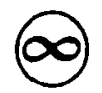

This volume is printed on acid-free paper by William S. Hein \& Co., Inc. 


\title{
The International and Comparative Law Quarterly
}

\author{
EDITORIAL BOARD \\ Genetal Editor \\ Norman S. MarsH
}

Assistant General Editor

Elizabeth Eratt

\begin{abstract}
Editors
Public International Law

Private International Lavo

D. H. N. Jomongos

P. B. Carter
\end{abstract}

Comparative Lazo

A. K. R. Kraufy

() 1965

Britiab Inetitate of International and Comparative Law 


\section{TABLE OF CONTENTS}

\section{ARTICLES AND NoTES}

(An alphabetical Index of Authors, together with Subject Index, Book Reviews Index, and Table of Cases is to be found at the end of this Volume.)

\section{ARTICLES}

P. R. H. Webb and lan Brownlie: Survival of Actions in TORT AND THB CONFLICT OF LAWS .

PAGE

Finn Seyersted: JURISDICTION OVER ORGANS AND OFFICIALS OF States, The Holy See and Intergovermagntal ORGaNisations (1) . Hungdah Chiu: SUCCESSION In INTERNATIONAL ORGanisations S. Prakash Sinha: Perspective of THE Newly Independent States on THE Binding QUaltTy OF INTBRNational LAW

E. J. Cohn: The Rules of ARBItration OP THE INTERNATIONAL CHAMBer OF COMMERCE

Nicholas S. Wilson: FreEdOM OF CONTRACT aND AdHESION Contracts . ..$\quad \cdot$.. .

Patricia $M$. Webb: BREAKDOWN versus FaUli-REcent Changes in UNTtBd Kingdom aNd New Zbaland DIVORCB LAW . . . . . . . .

Graham E. Parker: The Education of the SENTENCDng Judge J. N. D. Anderson: Recent Reforms IN THE Islamic LAW OF INHERITANCB

A. N. Allott: TOWARDS the UNIFICATION OP LAWS IN AFrica

Hamish $R$. Gray: ThB Development AND Function OF tHE LAW OP TORT IN THE TWENTIETH CENTURY IN Australla AND New Zraland . $. \quad . \quad . \quad$.

N. March Hunnings: PrRate Broadcasting in European Waters

Ian Brownlie: SOME LegAl ASPECTS OF THE USE OF NuCLEAR WEAPONS

K. R. Simmonds: The SAbatino CASE AND the Act of State DOCTRINE.

Finn Seyersted: JURISDICTion OVER ORgans aNd OFFICIALS OF STATES, THE HOLY SEE AND INTERgOVERNMENTAL Organisations (2) .

R. H. Graveson: THB TeNTH Session OF the Hague CoNferBNCB OF PrTVate INTERnational Law . .

P. M. Noth: Declaratory JUDGMENTS IN THE Divorce COURT . . . . . . . .

Dr. Walter Hallstein: THE EEC COMMISSION: A NEW FACTOR IN INTERNATIONAL LIFE .

C. D. Lush: THE Relationship BetwBen BerLnN aND the Federal Republic of Germany . . . . . 
R. P. Anand: The Role of Individual and Dissenting OpINIONS IN INTERNATIONAL ADJUDICATION . .

Stojan Cigoj: International Regulation of Civil Liabiltty
For Nuclank Risk. . . . . . .

William Latey: Conflicts of JURISDICTION In MATrimonial Causes

H. Street: Thr Twentieth Century Development aND FUNCTION OF THE LAW OF TORT IN ENGLAND. .

Chanan Singh: The Republican Constitution of Kenya: Historical BACKGROUND AND ANALYSIS. . .

Phiroze K. Irani: The CoURTS AND the Legislature in INDIA $A$. $K$. $R$. Kiralfy: Employers' aNd Employens' Civil LiaBILITY IN SOVIET LAW FOR INDUSTRIAL ACCIDENTS .

Frank E. Figgures, C.M.G.: Legal ASPECTS of the EUROPEAN Free Tradb Association. . . . . .

Andre Tunc: The Twentieth Century Development and Function of THE LAW OF TORTS IN France.

Roger Warren Evans: French aNd German ADMINISTRative LAW: WTTH SOME ENGLISH COMPARISONS . . .

Dr. L. Faragó: Decisions of thb Hungarian Chamber of Commerce in " Comecon" Arbitrations . . .

S. $\boldsymbol{K}$. B. Asante: Fiduciary Principles in Anglo-American Law and the Customary law of Ghana-a ComPARATIVE STUDY . . . . . . . .

L. F. E. Goldie: Liabiltty for Damage and the Progressive Development OF INTERNational LAW

Clifton E. Wilson: Diplomatic Privileges and Immunities: The Retinue and Families of the Diplomatic STAFF . . . . . . . . . . .

Luke T. Lee: The Mexico City Conference of the United Nations Special Committee on Principles of International Law Concerning Friendly Relations aNd Co-opbration among Statzs.

P. R. H. Webb and P. M. North: Thoughts on the Place of COMMISSION OF A NON-StatUTORY TORT . . .

\section{NOTES AND COMMENTS}

The Finnish-Soviet Treaty relating to the Saima Canal, Helmut R. Külz ..$\quad$. . . . .

State Succession to Treaties in the Commonwealth: A Rejoinder. A. P. Lester. $\cdot$ - $\cdot$ i

Jurisdiction to Grant Doclaratory Judgments as to Marital. Status (Based on Garthwaite v. Garthwaite), Anthony Hooper the Eddying Winds Based on Shahnaz v. Polygamy and the Eddying Winds (Based on Shahnaz v. Rizwan), P. R. H. Webb. . . . . .

Proof of Foreign Law in Sweden, Ruth Ginsburg . . . . 277 
European Lawyers at Leiden

PAGE

1. The Draft European Patent Convention, Geoffrey W. Tookey

2. "Internatio" \& "Puttershoek" cases, Dennis Thompson . . . . . .

Protection of the Family against Disinheritance in American

Law. William F. Fratcher. . . . . .

Problems of Israeli Maritime Law, $R$. Gottschalk . . .

West Indian Views of Palm Tree Justice and Section 17 of the

Married Women's Property Act, A. Bissett-Johnson

The Treaty Law of the United States, Erwin C. Surrency.

Jamaica assumes Treaty Rights and Obligations: Some Aspects of Foreign Policy, L. B. Francis .

A Time Limit for Punishment of War Crimes? translated by J. E. S. Fawcett .

Some Constitutional Notes on the Fifteenth Congress of the Universal Postal Union, H. G. Schermers.

Withdrawal from the United Nations-Indonesia, F. Livingstone

The Legal Programme of the Council of Europe tion, B. D. Inglis

Bigamy and Capacity to Marry. Based on Schwebel v. Ungar (or Schwebel), P. R. H. Webb.

Wardship of Court and the Conflict of Laws (Based on Re Kernot (An Infant) and Re P. (G. E.) (An Infant)). P. R. H. Webb.

Private International Law and German Matrimonial Law, (Based on a decision of the German Federal Court), Paul Abel.

Consideration and Gift, Walter Stern
The Promissory Note in Latin America: A Commercial Guide, C. D. M. Wilde.

An Indemnity for the Cost of Litigation in Australia, B. N. Misra

The Grouping of Enterprises for Joint Ventures, Dennis Thompson

On the Sacrosanctity of the Foreign Act of State, $\dot{F} . A$. Mann Enforcement of the Revenue Laws of Another State (Based on Commissioner of Taxes (Federation of Rhodesia and Nyasaland) v. McFarland), Erwin Spiro

Undissolved Christian Monogamous Marriage, followed by Mohammedan Marriage-Bigamy? (Based on A.G. of Ceylon v. Reid), P. R. H. Webb

Locus Delicti (Based on Abbot-Smith v. Governors of the University of Toronio), David McClean . . .

The Case of Demolitions (Based on Burmah Oil Co. (Burma Trading) Ltd. v. Lord Advocate), T. C. Daintith.

The Formation of International Contracts, with Reference to the Uniform Law on Formation, Michael Aubrey.

The Polish Code of Family Law, 1964, D. Lasok . . . 1022 
Note on Italian Law, M. A. Milner . . . . . . . 1028

Law and Lawyers in Saudi Arabia, Samir Shamma . . . 1034

The Alien Enemy hearing Board as a Judicial Device in the United States during World War $\Pi$, Charles V. Harris 1360

Private International Law and Personal Law (Based on Duggamma v. Caneshayya) J. Duncan M. Derrett . 1370

The Commission of the EEC and Restrictive Trading Agreements, Alan Campbell

A Note on the Limitation of the Doctrine of Stare Decisis in the Republic of Ireland. Colum Gavan Duffy . . 1382

A Note on Liability of Shipowners in Queensland, B. N. Misra 1394 Provocation as a Defence Under the Nigerian Criminal Code. A. B. Kasunmu and S. A. Omabegho . . . 1399

The Israeli Standard Contracts Law, 5724-1964, A ubrey $L$. Diamond

CURRENT LEGAL DEVELOPMENTS . . 696, 1040, 1417 BOOK REVIEWS . . . . . . . 313, 699, 1045, 1423

BOOKS RECEIVED . . . . . . 344, 723, 1073, 1453

INDEX FOR VOLUME 14 . $\quad . \quad . \quad . \quad . \quad . \quad$. 1457

Contributors . . . . . . . . . . 1457

Subject Index . . . . . . . . . . . . . . 1460

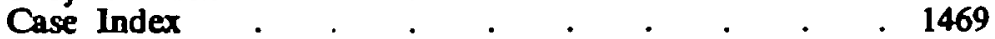

Book Index . . . . . . . . . . . . . . 1470 